\title{
Oridonin inhibits migration, invasion, adhesion and TGF-ß1-induced epithelial-mesenchymal transition of melanoma cells by inhibiting the activity of PI3K/Akt/GSK-3ß signaling pathway
}

\author{
CHUN-YU LI ${ }^{1}$, QI WANG ${ }^{2}$, SHEN SHEN $^{1}$, XIAO-LU WEI $^{1}$ and GUO-XIA LI ${ }^{1}$ \\ ${ }^{1}$ Department of Integrated Chinese Traditional and Western Medicine, \\ International Medical School, Tianjin Medical University, Tianjin 300070; ${ }^{2}$ Department of Oncology, \\ Shanghai Pulmonary Hospital Affiliated Tongji University, Shanghai 200433, P.R. China
}

Received July 22, 2017; Accepted November 7, 2017

DOI: 10.3892/ol.2017.7421

\begin{abstract}
Epithelial-mesenchymal transition (EMT) has been reported to play pivotal roles in tumor invasion and metastasis. Inhibition of EMT may exert beneficial effects in regulating metastasis. Oridonin (ORI), an active diterpenoid compound isolated from Rabdosia rubescens, was found to be a potent anti-metastatic agent. However, the possible involvement of ORI in the EMT in malignant melanoma is unclear. The present study found that ORI inhibited cell migration, invasion, and adhesion in A375 and B16-F10 melanoma cells. The transforming growth factor- $\beta 1$ (TGF- $\beta 1$ )-induced EMT was also inhibited in ORI-treated cells, as reflected in the upregulation of E-cadherin, and downregulation of vimentin and Snail. Similar results were observed in A375 and B16-F10 melanoma cells treated with ORI. Furthermore, pre-treatment with ORI blocked the TGF- $\beta 1$-induced phosphoinositide 3-kinase (PI3K)/AKT serine/threonine kinase (Akt)/glycogen synthase kinase (GSK)-3 $\beta$ signaling pathway activation. These effects mimicked PI3 kinase inhibitor LY294002 treatment. ORI interfered with the PI3K/Akt/GSK-3 $\beta$ pathway, and reversed TGF- $\beta 1$-induced EMT, which suppressed the invasion and metastasis of melanoma cells. Taken together, the present study demonstrated that ORI inhibits melanoma cells migration, invasion, and adhesion and TGF- $\beta 1$-induced EMT through the PI3K/Akt/GSK-3 $\beta$ signaling pathway. These findings suggest that ORI is a promising anti-metastasis agent for melanoma.
\end{abstract}

Correspondence to: Dr Chun-Yu Li, Department of Integrated Chinese Traditional and Western Medicine, International Medical School, Tianjin Medical University, 22 Qixiangtai Road, Heping, Tianjin 300070, P.R. China

E-mail: lichunyu@tmu.edu.cn

Key words: oridonin, melanoma, migration, invasion, adhesion, epithelial-mesenchymal transition

\section{Introduction}

Metastasis is responsible for the majority of melanoma related deaths $(1,2)$. The median survival time of patients with metastatic melanoma is $8-9$ months and the 3 -year overall survival rate is $<15 \%$ (3). Therefore, there is an urgent need to identify novel therapeutic strategies for melanoma metastasis and the search for a new agent with low toxicity that can inhibit metastasis with clear molecular targets has attracted scientist's attention.

Epithelial-mesenchymal transition (EMT), the transformation of epithelial cells into motile mesenchymal cell phenotypes, is one of the essential events in tumor progression particularly in tumor invasion and metastasis (4-6). During EMT, epithelial cells lose polarity and cell-to-cell contacts, followed by dramatic remodeling of the cytoskeleton and acquisition of migratory, invasive, and stem cell-like properties $(7,8)$. The most well-characterized factor responsible for induction of EMT is transforming growth factor- $\beta 1$ (TGF- $\beta 1$ ) (9). There are several signaling pathways related to TGF- $\beta 1$-induced EMT in cancer cells, including the PI3K/Akt, Wnt/ $\beta$-catenin and Smads-dependent pathways. PI3K/Akt/GSK-3 $\beta$ signaling pathways are overactive in cancer cells, thus reducing apoptosis, allowing proliferation, and promoting invasion and metastasis (10-13). Therefore, inhibition of the PI3K/Akt/GSK-3 $\beta$ signaling pathway-mediated EMT may exert beneficial effects in treating cancer patients with advanced metastasis.

Traditional Chinese medicinal plants or their active components have been widely and successfully used in treating human cancers (14-16). Oridonin (ORI), an active diterpenoid compound isolated from Rabdosia rubescens, is currently one of the most important active Chinese medicinal components. Previous studies have demonstrated that ORI possesses multiple biological activities such as anti-inflammatory, neuroprotective, anti-bacterial, and antitumor effects. ORI shows broad-spectrum anti-proliferative activity in various types of cancer (16-21). Notably, several studies reported that ORI also demonstrates significant anticancer activity in skin melanoma. 
For instance, $\mathrm{Gu}$ et al reported that ORI potently impairs the capability of survival and proliferation of melanoma cells by induction of apoptosis (22). Wang et al reported ORI induces human melanoma A375-S2 cell death through inhibiting insulin-like growth factor-1 (IGF-1) receptor signaling (23).

However, the inhibiting effects of ORI in metastasis of melanoma cells and the underlying mechanisms of such effects remain unclear. Here, in this study, we demonstrated that ORI could effectively inhibit the migration, invasion, adhesion, and TGF- $\beta 1$-induced EMT in A375 and B16-F10 melanoma cells. Our data also demonstrated that the PI3K/Akt/GSK-3 $\beta$ pathway is involved in the reversion of TGF- $\beta 1$-induced EMT in A375 and B16-F10 cells when engaged with ORI. Our findings indicate that ORI may be a promising anti-metastasis candidate compound for melanoma therapy.

\section{Materials and methods}

Reagents and antibodies. ORI was acquired from Aladdin Biochemical (Shanghai, China), and dissolved in $0.5 \%$ dimethyl sulfoxide (DMSO). To make sure the ORI solution was sterile it was filtered using a $0.2 \mu \mathrm{m}$ filtration membrane before it was added to the culture medium for the in vitro assays. 3-(4,5-Dimethyl-2-thiazolyl)-2,5-diphenyl-2H-tetrazolium bromide (MTT), LY294002 (an inhibitor of PI3K), and DMSO were purchased from Sigma-Aldrich; Merck KGaA (Darmstadt, Germany). Phosphatase inhibitor cocktail tablets were purchased from Roche Molecular Biochemicals (Indianapolis, IN, USA). TGF- $\beta 1$ was purchased from Millipore (Billerica, MA, USA). Dulbecco's modified Eagle's medium (DMEM), fetal bovine serum (FBS) and penicillin/streptomycin were purchased from Gibco (Thermo Fisher Scientific, Inc., Waltham, MA, USA). All other chemicals were of analytical reagent grade. The antibodies used were as follows: Anti-E-cadherin was purchased from BD Biosciences (Franklin Lakes, NJ, USA). Anti-vimentin was purchased from Epitomics (Burlingame, CA, USA). Anti-Snail, anti-Akt, and anti-phospho-Akt (Ser473) were purchased from Cell Signaling Technology, Inc. (Danvers, MA, USA). Anti-PI3K, anti-phospho-PI3K (Tyr458), anti-GSK-3 $\beta$, anti-phospho-GSK-3 $\beta$ (Ser9) and anti- $\beta$-catenin were purchased from Abcam (Cambridge, MA, USA). Anti- $\beta$-actin, goat anti-mouse IgG-HRP, and goat anti-rabbit IgG-HRP were purchased from Santa Cruz Biotechnology, Inc. (Dallas, TX, USA). All antibodies were diluted at 1:1,000 except where specified.

Cell lines and cell culture. A375 human melanoma cell line obtained from ATCC (Manassas, VA, USA). B16-F10 (mouse melanoma) cell line was purchased from the Cell Culture Center of Chinese Academy of Medical Sciences (Beijing, China). The cells were cultured in DMEM supplemented with $10 \% \mathrm{FBS}, 100 \mathrm{U} / \mathrm{ml}$ penicillin, and $100 \mu \mathrm{g} / \mathrm{ml}$ streptomycin. All cell cultures were maintained at $37^{\circ} \mathrm{C}$ in an atmosphere containing $5 \% \mathrm{CO}_{2}$.

Cell viability assay (MTT assay). Cell viability was measured by MTT assay to evaluate the effect of ORI on cell proliferation (24). A375 or B16-F10 cells in the logarithm phase were seeded in 96 -well plates at the density of $5 \times 10^{3}$ cells/well.
When the cells were adherent to the walls, the cells were treated with ORI at indicated concentrations for $24 \mathrm{~h}$ followed by adding $100 \mu \mathrm{l}$ of MTT ( $1 \mathrm{mg} / \mathrm{ml})$ and incubating for $4 \mathrm{~h}$. Then, the medium was removed and $150 \mu \mathrm{l}$ of DMSO was added to each well. Absorbance of each well was detected under $490 \mathrm{~nm}$ by microplate reader (BioTek Instruments, Inc., Winooski, VT, USA). The test was repeated three times. Inhibition rate $(\%$ of control $)=(1-$ absorbance of test sample/absorbance of control) x $100 \%$.

Wound-healing migration assay. Cell migration wounding assay was performed according to the protocol described previously (25,26). A375 or B16-F10 cells were cultured in $60 \mathrm{~mm}$ dishes at the density of $8 \times 10^{5}$ cells/dish to $100 \%$ confluency. After wounding with pipette tip, the cells were washed with PBS and serum free medium to which indicated concentrations of ORI had been added. Then, the cells were allowed to migrate for $24 \mathrm{~h}$ at $37^{\circ} \mathrm{C}$ in $5 \% \mathrm{CO}_{2}$. At predetermined time-points $(0$, $3,6,9,12$ and $24 \mathrm{~h}$ ), the widths of wound were measured and images of cells were taken at time 0 and $24 \mathrm{~h}$ with a microscope (IX50; Olympus, Tokyo, Japan). The assay was carried out double blind to eliminate the deviation induced by subjective factors. The test was repeated three times.

Matrigel invasion assay. Cell invasion was detected by Transwell assay $(26,27)$. After pre-treatment with indicated concentrations of ORI for $24 \mathrm{~h}$, A375 or B16-F10 cells were harvested and seeded to the upper chamber which was coated with matrigel (BD Biosciences) at the density of $3 \times 10^{4}$ cells/well in serum free medium. The lower chambers were filled with standard medium. The cells were allowed to invade for $24 \mathrm{~h}$ incubated at $37^{\circ} \mathrm{C}$ in $5 \% \mathrm{CO}_{2}$. The invading cells were fixed with methanol. Cell numbers were counted in five separate fields using the computer-based microcopy imaging system. The assay was carried out double blind to eliminate the deviation induced by subjective factors. The test was repeated three times.

Cell-matrix adhesion assay. After pre-treatment with indicated concentrations of ORI for 24 h, A375 or B16-F10 cells were harvested, re-suspended in serum free medium at the density of $2 \times 10^{5}$ cells/well and seeded to the 24 -well plates coated with fibronectin $(10 \mathrm{ng} / \mathrm{ml})$. After further incubations for 5, 15 and $30 \mathrm{~min}$, non-adherent cells were removed by PBS washes. The adherent cells were fixed with methanol and counted in five separate fields under a light microscope $(28,29)$. The assay was carried out double blind to eliminate the deviation induced by subjective factors. The experiment was repeated three times.

Quantitative real-time polymerase chain reaction ( $R T-P C R)$. After pre-treatment with indicated concentrations of ORI for $24 \mathrm{~h}$, The total RNA of A375 or B16-F10 cells was extracted by TRIzol reagent (Roche, Suisse). Reverse transcription was carried out with fast quant RT kit (Tiangen, Beijing, China). The procedure was based on the protocol provided by Tiangen. The real-time PCR mixture volume was $25 \mu \mathrm{l}$ including $12.5 \mu \mathrm{l}$ SYBR Green mix, $0.2 \mu \mathrm{l}$ cDNA, $1.5 \mu \mathrm{l}$ primer per mix $(10 \mu \mathrm{M}$ each primer), and $10.8 \mu \mathrm{l}$ RNAse-free $\mathrm{H}_{2} \mathrm{O}$. The experiment was then set up with the following PCR program on ABI 7500 (Applied Biosystems; Thermo Fisher Scientific, Inc., Waltham, 
MA, USA): $95^{\circ} \mathrm{C}$ for $15 \mathrm{~min}, 1$ cycle; 40 cycles of $95^{\circ} \mathrm{C}$ for $10 \mathrm{sec}, 60^{\circ} \mathrm{C}$ for $20 \mathrm{sec}, 72^{\circ} \mathrm{C}$ for $30 \mathrm{sec}$. Specific primers were designed by gene runner software and were synthesized by Beijing Aoke Biotechnology Co., Ltd. (Beijing, China). The specific primers are reported in Table $\mathrm{I}$. The $\mathrm{Ct}$ value was automatically calculated by software, the $\mathrm{Ct}$ values were all normalized against the quantity of the $\beta$-actin control RNA, and the relative quantification of gene expression was calculated by the $2^{-\Delta \mathrm{Ct}}$ method according to the formula: $\Delta \mathrm{Ct}$ (target gene $)=\mathrm{Ct}$ (target gene) $-\mathrm{Ct}$ (control gene). All assays were performed in triplicate and independently repeated 3 times.

Western blotting. Western blotting was used for detection of expressions of E-cadherin, vimentin, Snail, PI3K, phospho-PI3K, Akt, phospho-Akt, GSK-3 $\beta$, and phospho-GSK-3 $\beta$, anti- $\beta$-catenin in A375 and B16-F10 cells. After pretreatment with indicated concentrations of ORI and/or LY294002 (an inhibitor of PI3K) for $24 \mathrm{~h}$, cells were then stimulated by $10 \mathrm{ng} / \mathrm{ml} \mathrm{TGF}-\beta 1$ for $15 \mathrm{~min}$. Then the protein lysates from cultured cells were separated by $10 \%$ sodium dodecylsulfate polyacrylamide gel electrophoresis (SDS-PAGE) systems and transferred to polyvinyllidene difluoride (PVDF) membranes (Millipore). After blocking with 5\% skim milk in Tris-buffered saline (TBS) containing 0.1\% Tween-20 for $2 \mathrm{~h}$, the membranes were incubated with primary antibodies at 1:500-1:1,000 dilutions with 5\% BSA in TBST overnight at $4^{\circ} \mathrm{C}$. The antibodies were as follows: E-cadherin, vimentin, Snail, PI3K, phospho-PI3K, Akt, phospho-Akt, GSK-3 $\beta$, phospho-GSK-3 $\beta$, and anti- $\beta$-catenin. The blots were washed and incubated with secondary antibodies conjugated with horseradish peroxidase (HRP) and incubated for $1 \mathrm{~h}$ at room temperature. Membranes were visualized using enhanced chemiluminescence (immobilon ECL; Millipore) and were photographed using G-BOX (Gene Company Ltd., Beijing, China). The bands were analyzed by ImageJ software.

Statistical analysis. Each experiment was repeated at least three times. All data were expressed as mean \pm standard deviation (SD). Statistical Product and Service Solutions (version 19.0; SPSS, Inc., Chicago, IL, USA). P-value <0.05 was considered to indicate a statistically significant difference using one-way analysis of variance (ANOVA) test.

\section{Results}

Effects of ORI on the viability of A375 and B16-F10 cells. ORI, a diterpenoid purified from Rabdosia rubescens, has a molecular weight of $364.44 \mathrm{~g} / \mathrm{mol}$ and its molecular structure is shown in Fig. 1A. The inhibitory effect of ORI on the proliferation of melanoma cell lines A375 and B16-F10 were first detected by MTT assay. As shown in Fig. 1B and C, the survival rate of ORI $(5-20 \mu \mathrm{M})$ treated groups were $>90 \%$ at $48 \mathrm{~h}$, indicating that ORI at each of these concentrations alone had no anti-proliferative effect and did not cause any apparently cytotoxic effects in A375 and B16-F10 cells within $48 \mathrm{~h}$. However, when cells were treated with $40 \mu \mathrm{M}$ of ORI for $48 \mathrm{~h}$, the growth of A375 and B16-F10 cells was inhibited by ORI, but the inhibition rate of $40 \mu \mathrm{M}$ for $48 \mathrm{~h}$ was only $15 \%$ (Fig. 1B and C). These data indicate that $48 \mathrm{~h}$ of ORI (5-20 $\mu \mathrm{M})$ exposure has no significantly influence on the cell
Table I. Primers sequences used in quantitative polymerase chain reaction.

\begin{tabular}{|c|c|}
\hline Gene name & Primer sequence $\left(5^{\prime}-3^{\prime}\right)$ \\
\hline E-cadherin & $\begin{array}{l}\text { F: GGATTGCAAATTCCTGCCATTC } \\
\text { R: AACGTTGTCCCGGGTGTCA }\end{array}$ \\
\hline Vimentin & $\begin{array}{l}\text { F: GCAGGAGGCAGAAGAATGGTA } \\
\text { R: GGGACTCATTGGTTCCTTTAAGG }\end{array}$ \\
\hline Snail & $\begin{array}{l}\text { F: TCTAGGCCCTGGCTGCTACAA } \\
\text { R: CATCTGAGTGGGTCTGGAGGTG }\end{array}$ \\
\hline$\beta$-catenin & $\begin{array}{l}\text { F: TGAGGACAAGCCACAAGATTAC } \\
\text { R: TCCACCAGAGTGAAAA GAACG }\end{array}$ \\
\hline$\beta$-actin & $\begin{array}{l}\text { F: CCACGAAACTACCTTCAACTCCA } \\
\text { R: GTGATCTCCTTCTGCATCCTGTC }\end{array}$ \\
\hline
\end{tabular}

$\mathrm{F}$, forward; $\mathrm{R}$, reverse.

viability of A375 and B16-F10 cells. Thus, concentrations 5 and $10 \mu \mathrm{M}$ of ORI were used in the subsequent experiments.

ORI inhibits migration and invasion of A375 and B16-F10 cells. Cancer progression is associated with abrogation of the normal controls that limit cell migration and invasion. Cell invasion and migration are the initial and critical events in tumor metastasis and enhance the ability of a cancer cell to enter and exit the circulation to reach distant organs (30). The effect of ORI on cellular migration was investigated using a classic in vitro wound healing model. ORI was found to be effective in reducing cellular migration in A375 and B16-F10 cells (Fig. 2). The inhibitory effect of ORI on invasion of A375 and B16-F10 cells was examined using an invasion assay with matrigel-coated filters. In the absence of ORI (control group), A375 and B16-F10 cells displayed high invasive capability as indicated by being able to completely penetrate through the matrigel-coated filters. Activity of invasion of A375 and B16-F10 cells were markedly suppressed by $24 \mathrm{~h}$ exposure to ORI. At concentrations of 5 and $10 \mu \mathrm{M}$ of ORI, the number of cells able to penetrate through matrigel-coated filters was significantly decreased compared with control group (Fig. 3).

ORI inhibits adhesion in A375 and B16-F10 cells. The altered adhesiveness of tumor cells plays an important role in the formation of distal foci (31). The extracellular matrix (ECM) is a powerful regulator of cancer progression, which promotes transformation and regulates the tumor metastasis (32). Hence, we used fibronectin as the basement membrane to mimic the adhesion of A375 and B16-F10 cells. After the pre-treatment with indicated concentrations of ORI, the number of cells adhering to the fibronectin significantly decreased compared with the control group. Additional quantitative data are shown in Fig. 4. These data indicate that ORI inhibits the adhesiveness of A375 and B16-F10 cells adhering to fibronectin.

ORI regulates the expression of EMT markers in A375 and B16-F10 cells. EMT plays a key role in cancer progression. Enhanced cell migration and invasion properties are 
A

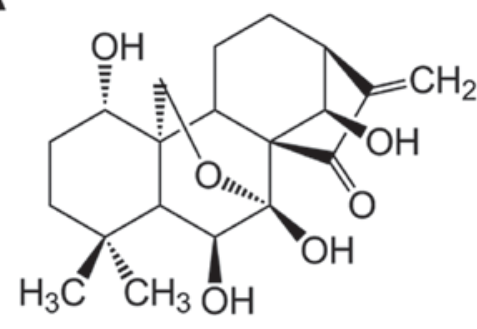
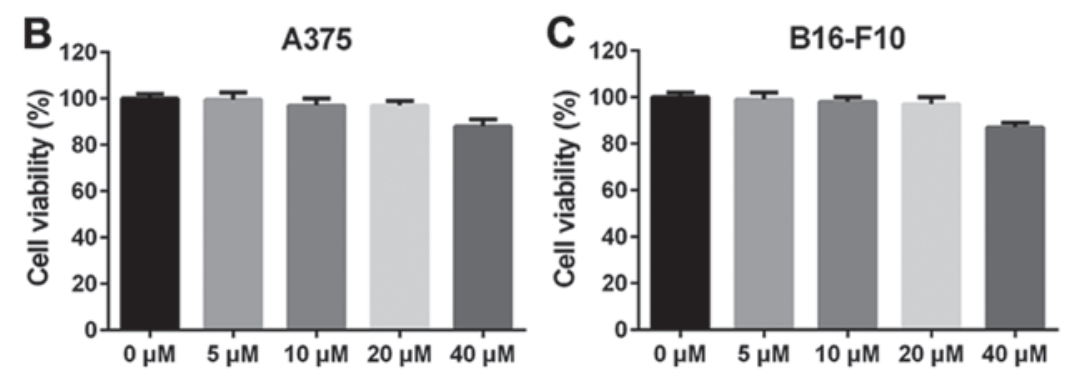

Figure 1. Effects of ORI on the viability of A375 and B16-F10 cells. (A) The chemical structure of ORI with a molecular weight $364.44 \mathrm{~g} / \mathrm{mol}$. (B) A375 and (C) B16-F10 cells were treated with indicated concentrations of ORI for $48 \mathrm{~h}$ and then cell viability was quantified by MTT assay. Values are the means \pm SD from three independent determinations.

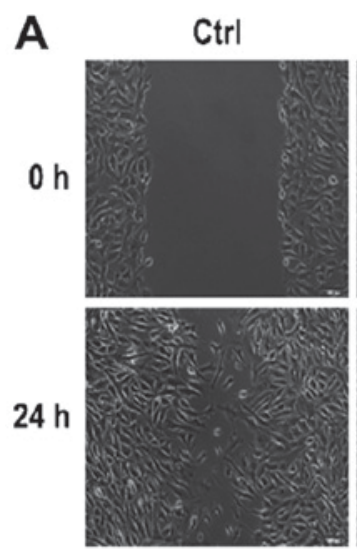

C

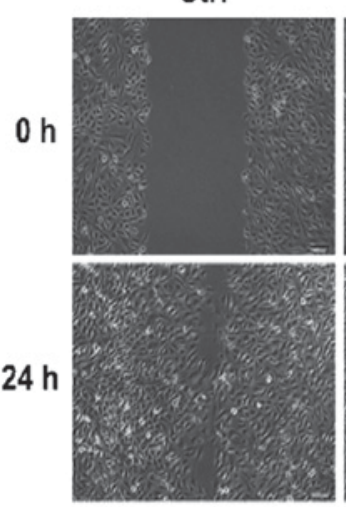

$5 \mu \mathrm{M}$
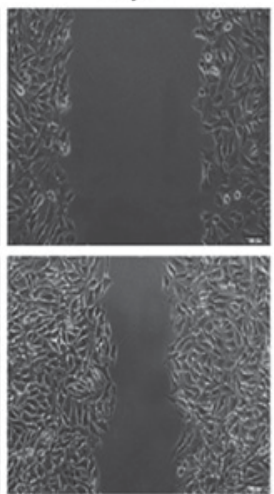

$5 \mu \mathrm{M}$

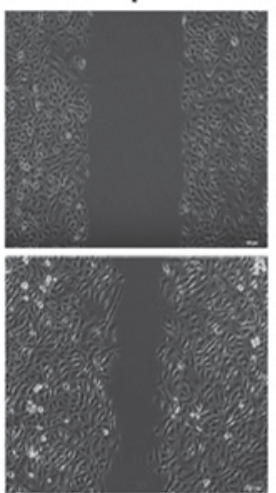

$10 \mu \mathrm{M}$

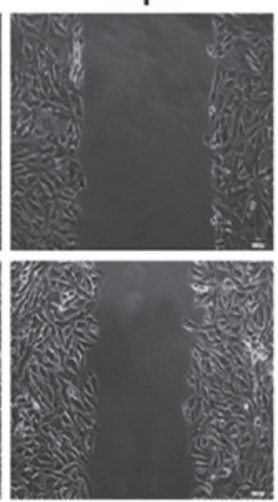

$10 \mu \mathrm{M}$

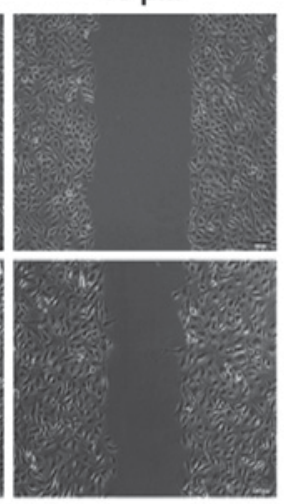

B

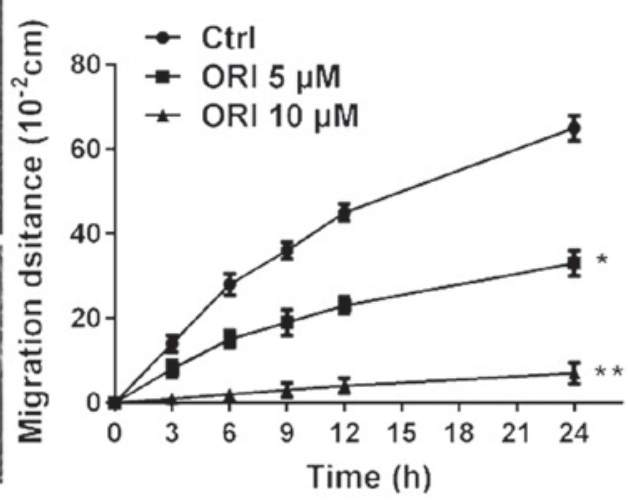

D

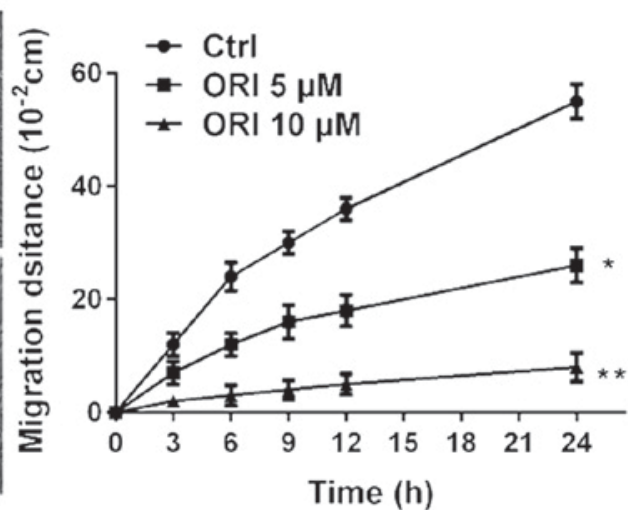

Figure 2. Effects of ORI on the migratory ability of A375 and B16-F10 cells. (A and B) A375 cells were treated with indicated concentrations of ORI for $24 \mathrm{~h}$. Images were taken at 0 and $24 \mathrm{~h}$ after the wound was made. (C and D) B16-F10 cells were treated with indicated concentrations of ORI for $24 \mathrm{~h}$. Images were taken at 0 and $24 \mathrm{~h}$ after the wound was made. The migration distance was measured using a software-based method. Values are the means \pm SD from three independent determinations. ${ }^{\mathrm{P}}<0.05$ and ${ }^{* *} \mathrm{P}<0.01$ compared with the control group.

important consequences of EMT (33). The most well characterized factor responsible for induction of EMT is TGF- $\beta 1$.
Snail as one of the transcriptional factors has been reported to be involved in the regulation of E-cadherin (34). The 
A

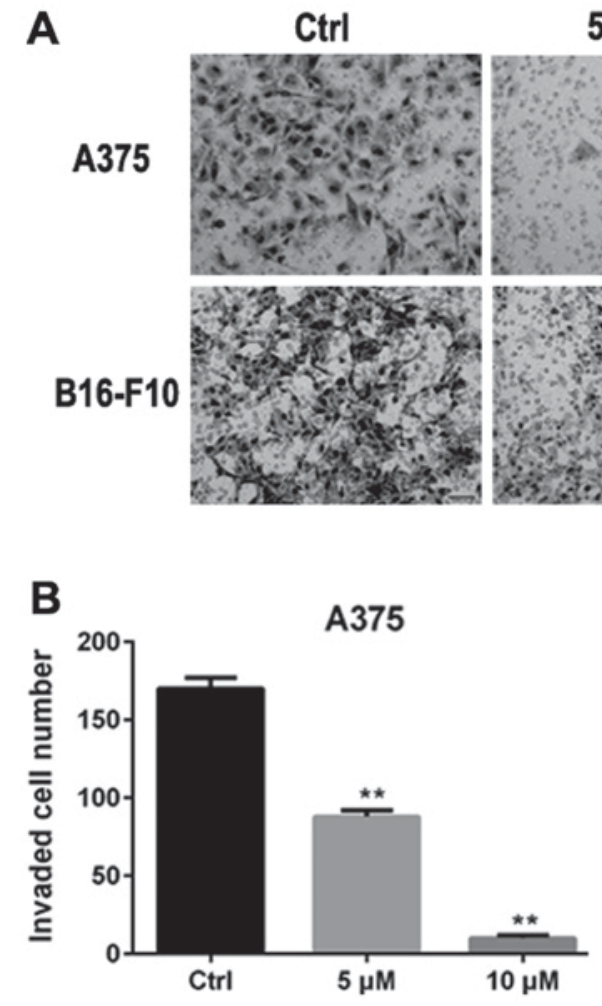

$5 \mu \mathrm{M}$
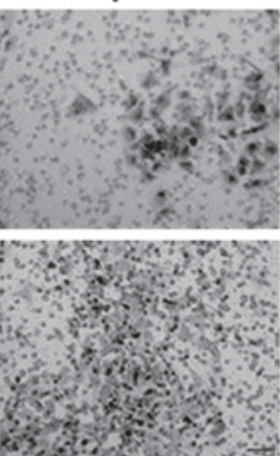

$10 \mu \mathrm{M}$

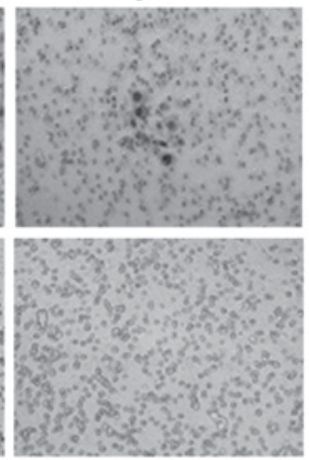

B

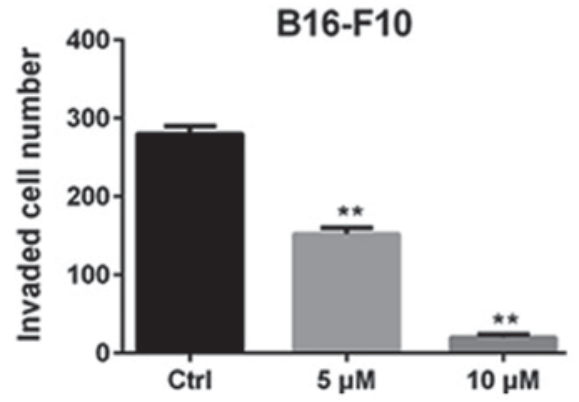

Figure 3. Effects of ORI on the invasion ability of A375 and B16-F10 cells. (A) A375 and B16-F10 cells were seeded and treated with indicated concentrations of ORI for $24 \mathrm{~h}$ and the number of invasive cells was determined using a transwell matrix penetration assay. (B) The cells which invaded were fixed with methanol and stained with Giemsa. Cell numbers were counted in five separate fields using the computer-based microcopy imaging system. Values are the means \pm SD from three independent determinations. ${ }^{* *} \mathrm{P}<0.01$ compared with the control group.
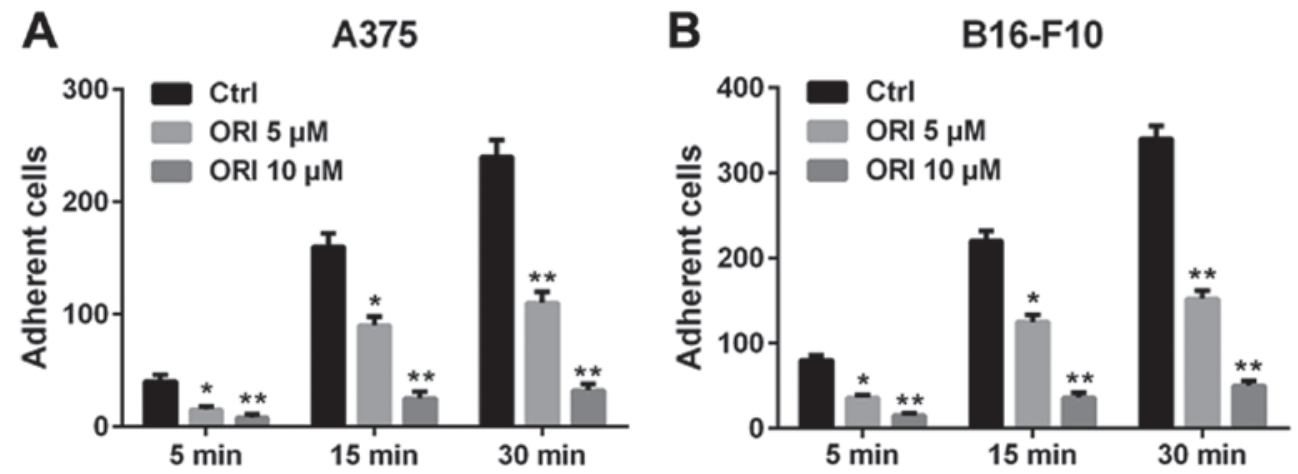

Figure 4. Effects of ORI on the adhesion ability of A375 and B16-F10 cells. (A) A375 and (B) B16-F10 cells were pre-treated with indicated concentrations of ORI for $24 \mathrm{~h}$, followed by measuring adhesion capacity on fibronectin over indicated time periods. Cell numbers in five fields were counted for each slide under the microscope with $20 \mathrm{x}$ magnitudes. Values are the means \pm SD from three independent determinations. ${ }^{*} \mathrm{P}<0.05$ and ${ }^{* *} \mathrm{P}<0.01$ compared with the control group.

accumulation of cytoplasmic $\beta$-catenin and its subsequent nuclear translocation is also a key event in EMT (35). Here we investigated the effect of ORI on TGF- $\beta 1$-mediated EMT in A375 and B16-F10 cells by qRT-PCR and western blotting. As shown in Fig. 5, TGF- $\beta 1$ reduced the expression of the epithelial marker E-cadherin and enhanced the expression of the mesenchymal marker vimentin. Snail and $\beta$-catenin expression levels were also enhanced, induced by TGF- $\beta 1$. Our data demonstrate that the effects of ORI are dose dependent increasing the expression of E-cadherin and decreasing the expression of vimentinin, Snail and $\beta$-catenin in A375 and B16-F10 cells compared with control group.
ORI suppresses the PI3K/Akt/GSK-3 $\beta$ signaling pathway in A375 and B16-F10 cells. Recent studies demonstrated that aberration of PI3K/Akt/GSK-3 $\beta$ signaling pathway is a very common mechanism for many human cancers including melanoma, since it can mediate survival, apoptosis, migration and invasion pathways (36). A growing number of studies showed that inhibition of PI3K/Akt/GSK-3 $\beta$ pathway could inhibit the migration and invasion of cancer cells $(37,38)$. Hence, we investigate the effects of ORI on the PI3K/Akt/GSK-3 $\beta$ signaling pathway in A375 and B16-F10 cells. As shown in Fig. 6, TGF- $\beta 1$ significantly increased the protein expression levels of p-PI3K, p-Akt and p-GSK-3 $\beta$ in both types of 


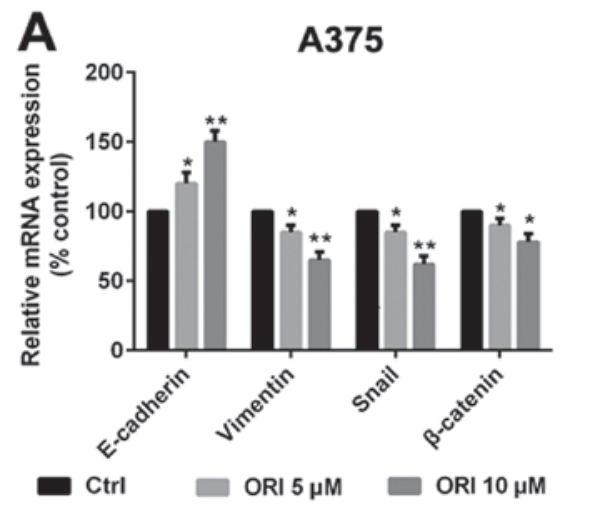

B
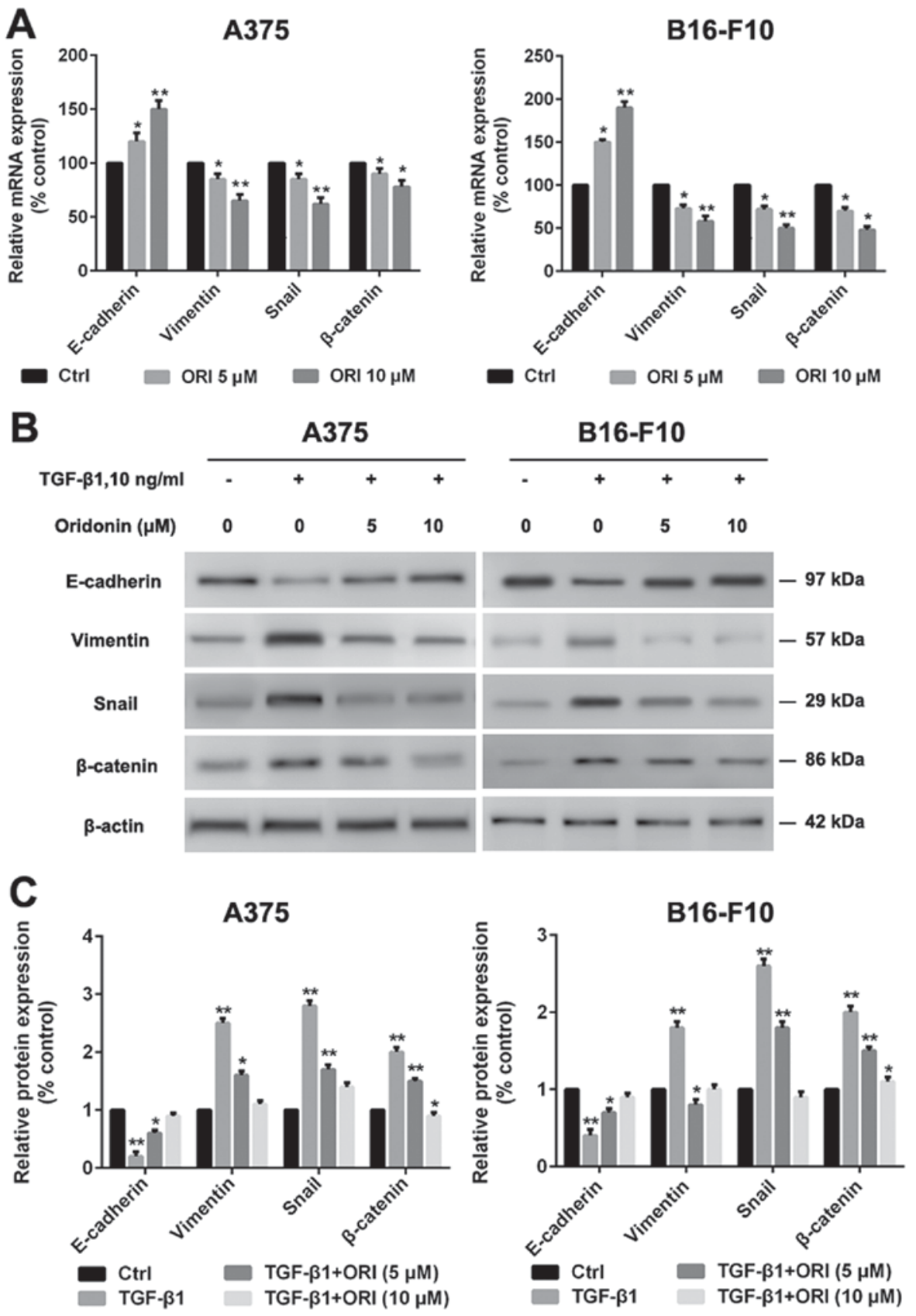

Figure 5. Effects of ORI on EMT-related marker's mRNA and protein expression. (A) A375 and B16-F10 cells were pretreated with indicated concentrations of ORI for $24 \mathrm{~h}$, followed by qRT-PCR assay to measure the regulatory effect of ORI on mRNA expression of E-cadherin, vimentin, Snail and $\beta$-catenin. (B) A375 and B16-F10 cells were pre-treated with indicated concentrations of ORI for $24 \mathrm{~h}$, followed by western blotting to test the protein expression of E-cadherin, vimentin, Snail and $\beta$-catenin. $\beta$-actin was used as loading control. (C) Relative protein expression for all proteins qualified using ImageJ software, respectively. The graph represents mean value of band intensity from three different western blots analyses. Values are the means $\pm \mathrm{SD}$ from three independent determinations. ${ }^{*} \mathrm{P}<0.05$ and ${ }^{* *} \mathrm{P}<0.01$ compared with the control group.

cells. Our studies have demonstrated that ORI has a significant inhibitory effect on TGF- $\beta 1$-mediated EMT, but the detailed effect mechanism is unclear. In the present study, we firstly examined the inhibitory activity of ORI against TGF- $\beta 1$-induced PI3K/Akt/GSK-3 $\beta$ pathway phosphorylation. The data demonstrated that ORI could downregulate the levels of p-PI3K, p-Akt and p-GSK-3 $\beta$. It is necessary to verify whether ORI could inhibit the EMT through TGF- $\beta 1$ mediated PI3K/Akt/GSK-3 $\beta$ pathway. To verify this hypothesis, PI3K inhibitor LY294002 was used to block the PI3K/Akt pathway, then ORI and TGF- $\beta 1$ were added.
The data demonstrated that, LY294002 and ORI abolished the TGF- $\beta 1$-induced decrease in E-cadherin and increase

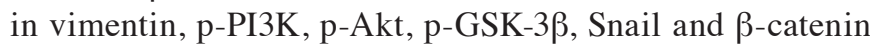
expression. ORI had little effect on E-cadherin, Vimentin, p-PI3K, p-Akt, p-GSK-3 $\beta$ and $\beta$-catenin (Fig. 7). There was no difference between their effects. ORI combined with LY294002 synergistically suppressed the related protein expression. The above data suggest that ORI may regulate the expression of E-cadherin and vimentin may work through $\mathrm{PI} 3 \mathrm{~K} / \mathrm{Akt} / \mathrm{GSK}-3 \beta$ signaling pathway, thereby in inhibiting TGF- $\beta 1$-induced EMT, which may be one of the mechanisms 


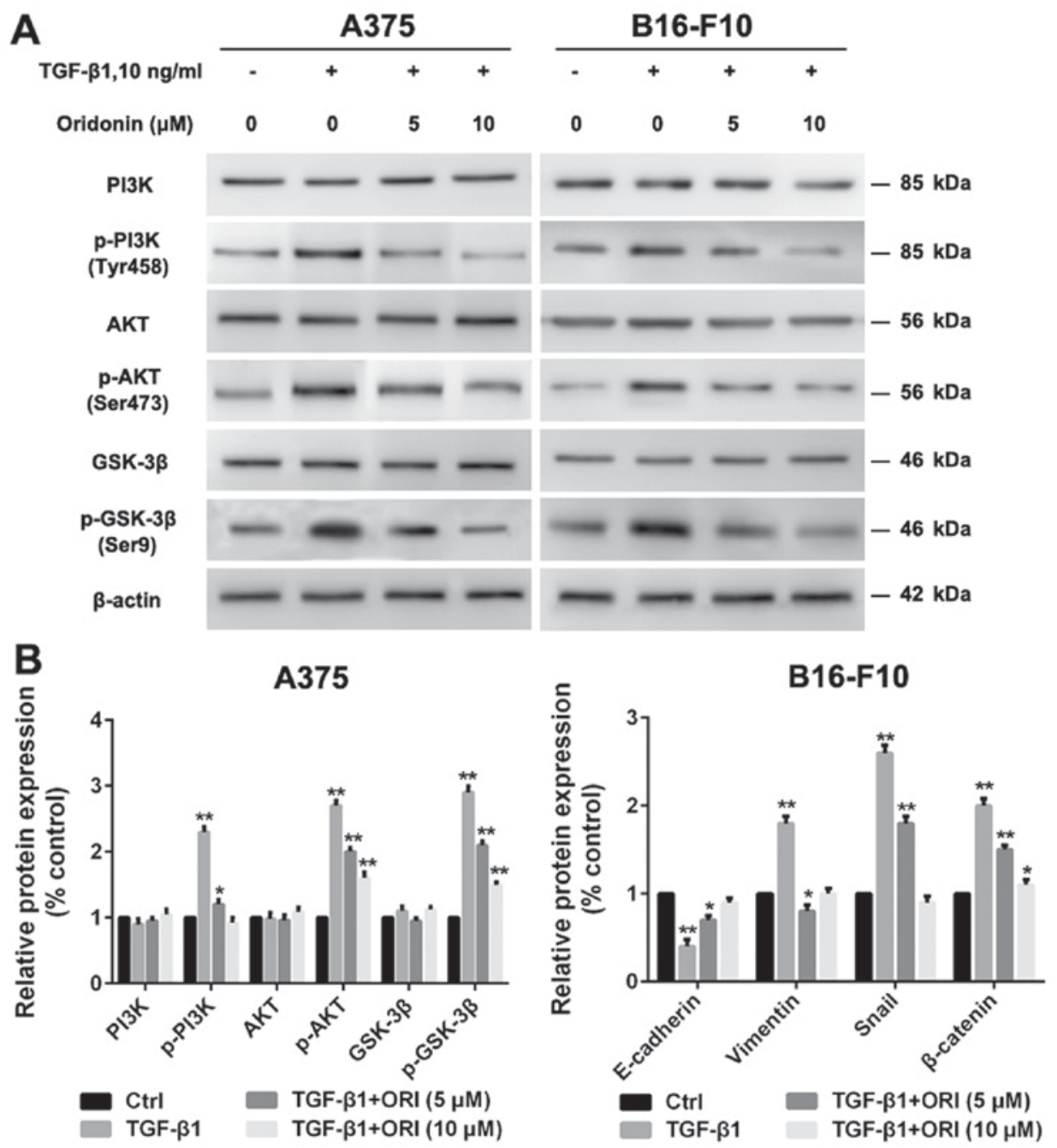

Figure 6. ORI affected the protein's expression of PI3K/Akt/GSK-3 $\beta$ signaling pathway in A375 and B16-F10 cells. (A) A375 and B16-F10 cells were pretreated with indicated concentrations of ORI for $24 \mathrm{~h}$. Then the total cell lysates were prepared and western blot analyses were performed for PI3K, Akt, GSK-3 $\beta$, p-PI3K, p-Akt, p-GSK-3 $\beta$. $\beta$-actin was used as loading control. (B) Relative protein expression for all proteins qualified using ImageJ software respectively. The graph represents mean value of band intensity from three different western blot analyses. Values are the means \pm SD from three independent determinations. ${ }^{*} \mathrm{P}<0.05$ and ${ }^{* *} \mathrm{P}<0.01$ compared with the control group.

through which ORI inhibited the A375 and B16-F10 cells migration and invasion.

\section{Discussion}

Melanoma is the most aggressive skin cancer and well-known for its poor prognosis and low survival rate (39). The high rate of metastasis is the main cause of death in patients with melanoma. Increased evidence demonstrates that mechanisms linked to melanoma metastasis are the induction of EMT, which is characterized by loss of epithelial phenotype, and acquiring fibroblast-like properties (40). They also exhibit reduced cell-cell adhesion and enhanced cell motility. Thus, exploring novel ways to inhibit or even reverse EMT process has attracted more attention.

Rabdosia rubescens is a well-known Chinese folk herbal medicine. For centuries, Rabdosia rubescens has been mainly used for inflammatory disorders such as sore throats and tonsillitis. It is suggested that the extraction of Rabdosia rubescens could delay tumor progress, improve patients quality of life and survival rates (41). ORI, an ent-kaurene diterpenoid, is the main active ingredient found in Rabdosia rubescens. Recently, ORI has attracted more and more attention due to its excellent antitumor activity against human melanoma, cervical, ovarian and hepatocellular cancers $(21,42)$. The anticancer mechanisms are mainly associated with triggering apoptosis, cell cycle arrest as well as autophagy and producing reactive oxygen species (43). Thus, the molecular mechanisms of anticancer activities of ORI are numerous and varied, depending on the cancer cell type or cell environment. In this study, our results first demonstrated the anti-metastatic capabilities of ORI and provided possible mechanisms responsible for its effects in melanoma cell lines.

In present study, ORI was dissolved in 0.5\% DMSO formed a stable and clear solution without micellar structure formation. As the solution of ORI added into the culture medium, the concentrations of DMSO was diluted 100 times (e.g., we added $30 \mu \mathrm{l}$ ORI solution into the $3 \mathrm{ml}$ culture medium for vitro migration assay). Hence, the final volume ratio of DMSO in culture medium was $0.005 \%$. As the MTT assay shown (Fig. 1B and C) the solvent control (added into the culture medium with $0.5 \%$ DMSO) has no significantly 
A

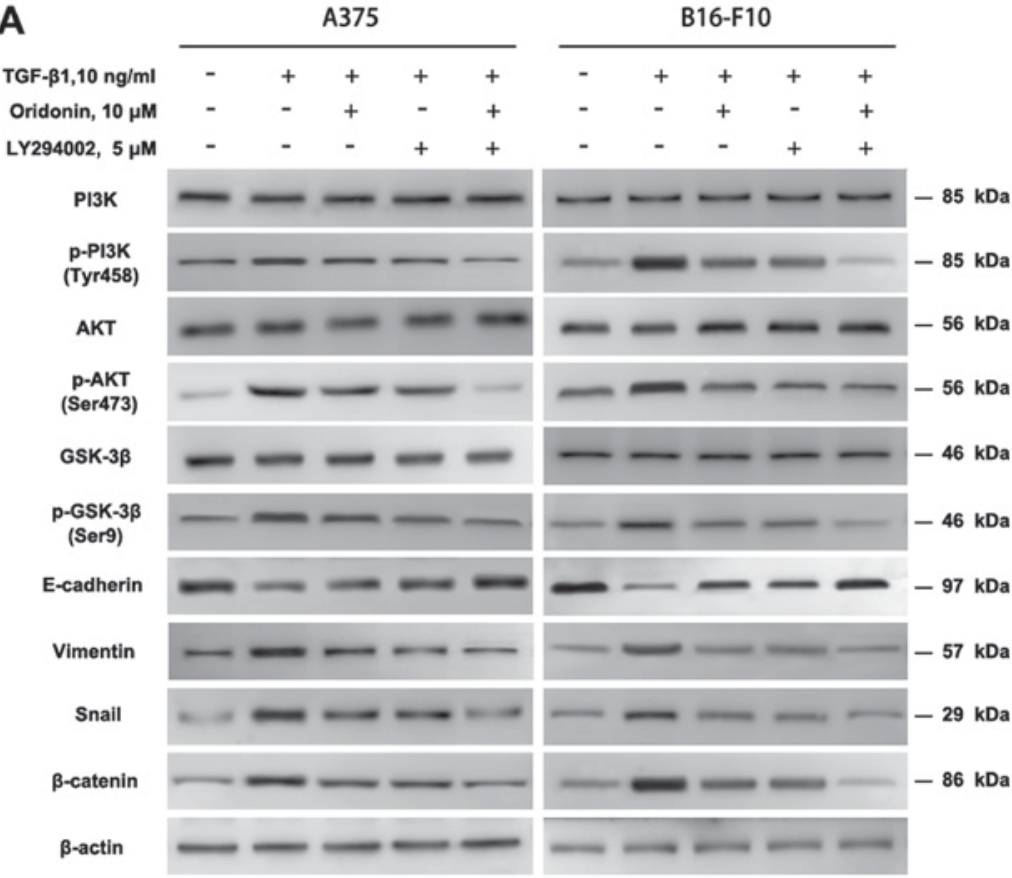

B

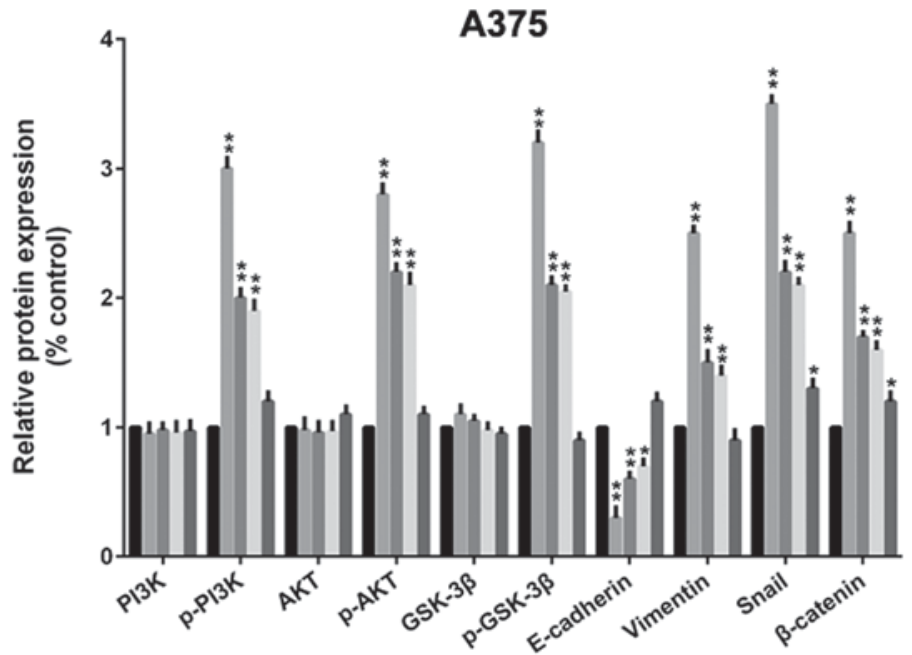

- Ctrl $=$ TGF- $\beta 1=$ TGF- $\beta 1+$ ORI $\square$ TGF- $\beta 1+$ LY294002 $\square$ TGF- $\beta 1+$ ORI+LY294002

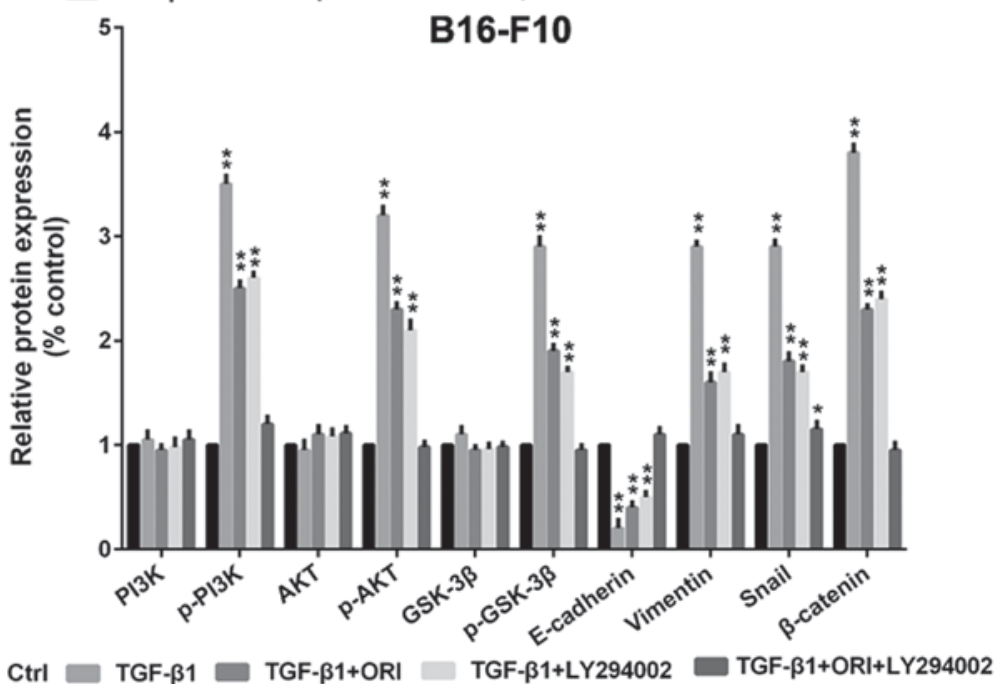

Figure 7. ORI and PI3K inhibitor LY294002 affected the proteins expression of PI3K/Akt/GSK-3 $\beta$ signaling pathway in A375 and B16-F10 cells. (A) A375 and B16-F10 cells were pre-treated with indicated concentrations of ORI or LY294002 for $24 \mathrm{~h}$. Then the total cell lysates were prepared and western blot

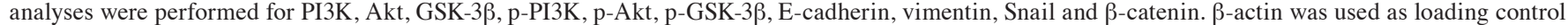
(B) Relative protein expression for all proteins qualified using ImageJ software respectively. The graph represents mean value of band intensity from theree different western blot analyses. Values are the means $\pm \mathrm{SD}$ from three independent determinations. ${ }^{*} \mathrm{P}<0.05$ and ${ }^{* *} \mathrm{P}<0.01$ compared with the control group. 


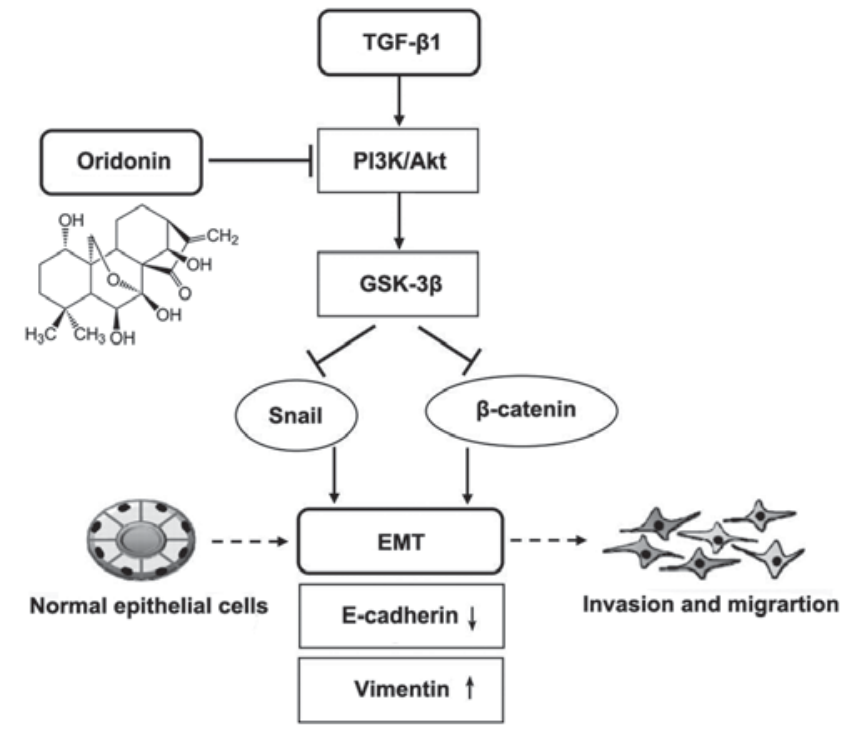

Figure 8. Schematic illustration of ORI inhibits TGF- $\beta 1$-induced EMT of melanoma cells through PI3K/Akt/GSK-3 $\beta$ signaling pathway.

influence on the cell viability of A375 and B16-F10 cells. As the literature reported, the cytotoxic activity of ORI varies a lot in different types of cancer cells $(42,44)$. Firstly, we evaluated the ORI's effect on melanoma cells proliferation by MTT assay aiming to exclude interference of cell proliferation on the results of motility properties assays. The melanoma cells proliferation was slightly affected by ORI at concentrations 5 and $10 \mu \mathrm{M}$ for a 48-h treatment, which is long enough for the subsequent motility properties assays. The anti-proliferation effect of one compound have relationship with many factors including the types of cells, the sensitivity of cells, the density of cells seeded in the plates, the time of the treatment and the reagents concentration used in the assay etc $(45,46)$. Our data showed that the viability of A375 and B16-F10 melanoma cells were not allergic to ORI's treatment compared with other cancer cell lines $(47,48)$. As the literature reported that ROS represents an initial and independent apoptosis pathway in melanoma cells (49). So we speculate that ORI can not trigger the ROS system inducing the apoptosis pathway in melanoma cells at lower concentrations (5 and $10 \mu \mathrm{M})$. The metastatic potential of cancer cells is mainly determined by their invasion, migration and adhesion abilities, which are commonly tested utilizing transwell systems with Matrigel-coated filters, wounding healing and adhesion assay. In this study, our results demonstrated that ORI at non-cytotoxic concentrations 5 and $10 \mu \mathrm{M}$ could significantly inhibit A375 and B16-F10 cells invasion, migration and adhesion in vitro (Figs. 2-4).

Molecules involving migration, invasion and adhesion of melanoma cells not only E-cadherin, vimentin, $\beta$-catenin and Snail. As we known, cancer metastasis is a complex process. EMT is positively correlated with the increased migration and invasion of cancer cells. During EMT, the switch of the immobile epithelial-like cancer cells to a motile mesenchymal-like phenotype requires alterations in migration, invasion and adhesion. Cells lose their epithelial traits and acquire mesenchymal characteristics, such as loss of the epithelial markers (E-cadherin, ZO-1, and $\beta$-catenin) and gain of the mesenchymal markers (N-cadherin and vimentin) (50).
Thus, generating a migratory phenotype. Melanoma cells have morphological changes after EMT (51). It also has been noted that the transcription factors, such as Snail, Slug and NF- $\kappa$ B etc. play important roles in regulating EMT. Snail is able to downregulate E-cadherin expression by binding to E-boxes in the E-cadherin promoter (52). Accordingly, we chose the classic EMT markers E-cadherin, $\beta$-catenin, vimentin and Snail for evaluation of the effect of ORI on EMT. TGF- $\beta 1$ is the most well characterized factor responsible for induction of EMT $(53,54)$. In our preliminary experiment, without the addition of TGF- $\beta 1$, the EMT marker not changed obviously in A375 and B16-F10 cells, so we can not well evaluated the ORI's effect on EMT (data not shown). As the data shown in Figs. 5-7, the addition of TGF- $\beta 1(10 \mathrm{ng} / \mathrm{ml})$ induced the EMT and activated the PI3K/Akt/GSK-3 $\beta 1$ signaling. Our results demonstrated that ORI could inhibit the TGF- $\beta 1$-induced EMT by inhibiting the activity of PI3K/Akt/GSK-3 $\beta$ signaling pathway. We did not design the group only exposure to ORI in this experiment. In the further study, we will set one group only exposure to ORI. The present data demonstrated that ORI markedly increase levels of E-cadherin and decrease levels of vimentin, Snail and $\beta$-catenin in A375 and B16-F10 cells (Figs. 5 and 6). These data indicate that ORI negatively regulates EMT, and markedly attenuates melanoma cells invasion, migration and adhesion in vitro.

To further understanding the cellular mechanisms responsible for our findings, we examined the status of the PI3K/Akt/GSK-3 $\beta$ signaling pathways associated with cancer cell invasion and metastasis (55). The PI3K/Akt signalling pathway plays an important role in several cellular physiological activities including proliferation, migration, invasion and adhesion; activation of this pathway by TGF- $\beta 1$ has been confirmed during the EMT process (56). Hyperactivation of $\mathrm{PI} 3 \mathrm{~K} / \mathrm{Akt}$ pathway has previously been reported in numerous human cancers. The PI3K/Akt pathway exerts its effects in cells by phosphorylating a variety of downstream molecules including GSK-3 $\beta$ in response to various stimuli. GSK-3 $\beta$, a major downstream target of Akt, is necessary for the maintenance of epithelial architecture, and inhibition of GSK-3 $\beta$ activity or expression results in a bona fide EMT (57). The active form of GSK-3 $\beta$ is in the dephosphorylated status, when it is phosphorylated by Akt at residue Ser-9, GSK-3 $\beta$ loses its activity. Furthermore, GSK-3 $\beta$ negatively regulates the transcription of Snail, a repressor of E-cadherin and an inducer of the EMT. Hence, inactivation of the PI3K/Akt signaling pathway could promote GSK-3 $\beta$ activity and suppress the expression of Snail, which in turn impedes the EMT (58). $\beta$-catenin signaling plays important roles in carcinogenesis and metastasis. Within the nucleus, $\beta$-catenin binds to the nuclear transcription factors, $\mathrm{T}$ cell factor/lymphoid enhancer factor (TCF/LEF), and regulates expression of various downstream adhesion junction genes including vimentin (59). In this study, our data demonstrated that ORI significantly inhibits phosphorylation of PI3K, phosphorylation of Akt, phosphorylation of GSK-3 $\beta$, and expression of Snail and $\beta$-catenin (Fig. 7). These results suggest that ORI may inhibit EMT in melanoma cells through attenuating the PI3K/Akt/GSK-3 $\beta$ signaling pathway.

In conclusion, the findings of the present study indicate that ORI could effectively inhibit migration, invasion and adhesion 
by inhibiting EMT in melanoma cells through its inhibition on the phosphorylation of PI3K, Akt, and GSK-3 $\beta$ in the presence of TGF- $\beta 1$. TGF- $\beta 1$ promoted the phosphorylation of $\mathrm{PI} 3 \mathrm{~K} / \mathrm{Akt}$, and then PI3K/Akt promoted the phosphorylation of GSK-3 $\beta$, in agreement with the results in Fig. 7A and B. As shown in Fig. 8, signaling mechanisms underline how ORI ameliorates TGF- $\beta 1$-induced EMT. Owing to the toxicity and attractive anticancer activity, ORI has become a promising anti-metastasis candidate compound for melanoma therapy. However, the effects and mechanisms of ORI need to be further elucidated in animal models and clinical trials. In addition, our results shed light on novel therapeutics in the prevention of melanoma cancer recurrence and metastasis.

\section{Acknowledgements}

This study was supported by the Natural Science Foundation of Tianjin Medical University (no. 2015KYZQ13), Postdoctoral Science Foundation of China (no. 2016M591398) and Basic Scientific Research Fund of Tianjin Medical University (no. 2016YD07).

\section{References}

1. Aviles-Izquierdo JA, Molina-Lopez I, Rodriguez-Lomba E, Marquez-Rodas I, Suarez-Fernandez R and Lazaro-Ochaita P: Who detects melanoma? Impact of detection patterns on characteristics and prognosis of patients with melanoma. J Am Acad Dermatol 75: 967-974, 2016.

2. Bowyer S, Prithviraj P, Lorigan P, Larkin J, McArthur G, Atkinson V, Millward M, Khou M, Diem S, Ramanujam S, et al: Efficacy and toxicity of treatment with the anti-CTLA-4 antibody ipilimumab in patients with metastatic melanoma after prior anti-PD-1 therapy. Br J Cancer 114: 1084-1089, 2016.

3. Balch CM, Gershenwald JE, Soong SJ, Thompson JF, Atkins MB, Byrd DR, Buzaid AC, Cochran AJ, Coit DG, Ding S, et al: Final version of 2009 AJCC melanoma staging and classification. J Clin Oncol 27: 6199-6206, 2009.

4. Duan H, Ma L, Liu H, Zhang Y, Zhang Z, Yan X and Li X: Tanshinone IIA attenuates epithelial-mesenchymal transition to inhibit the tracheal narrowing. J Surg Res 206: 252-262, 2016.

5. Ling G, Ji Q, Ye W, Ma D and Wang Y: Epithelial-mesenchymal transition regulated by $\mathrm{p} 38 / \mathrm{MAPK}$ signaling pathways participates in vasculogenic mimicry formation in SHG44 cells transfected with TGF- $\beta$ cDNA loaded lentivirus in vitro and in vivo. Int J Oncol 49: 2387-2398, 2016.

6. Ma Y, Xu X and Luo M: CXCR6 promotes tumor cell proliferation and metastasis in osteosarcoma through the Akt pathway. Cell Immunol 311: 80-85, 2017.

7. Le Coz V, Zhu C, Devocelle A, Vazquez A, Boucheix C, Azzi S, Gallerne C, Eid P, Lecourt S and Giron-Michel J: IGF-1 contributes to the expansion of melanoma-initiating cells through an epithelial-mesenchymal transition process. Oncotarget 7: 82511-82527, 2016.

8. Mao XY, Li QQ, Gao YF, Zhou HH, Liu ZQ and Jin WL: Gap junction as an intercellular glue: Emerging roles in cancer EMT and metastasis. Cancer Lett 381: 133-137, 2016.

9. Menezes ME, Shen XN, Das SK, Emdad L, Sarkar D and Fisher PB: MDA-9/Syntenin (SDCBP) modulates small GTPases RhoA and Cdc42 via transforming growth factor $\beta 1$ to enhance epithelial-mesenchymal transition in breast cancer. Oncotarget 7: 80175-80189, 2016.

10. Da C, Liu Y, Zhan Y, Liu K and Wang R: Nobiletin inhibits epithelial-mesenchymal transition of human non-small cell lung cancer cells by antagonizing the TGF- $\beta 1 / \mathrm{Smad} 3$ signaling pathway. Oncol Rep 35: 2767-2774, 2016.

11. Kim YJ, Jeon Y, Kim T, Lim WC, Ham J, Park YN, Kim TJ and $\mathrm{Ko} \mathrm{H}$ : Combined treatment with zingerone and its novel derivative synergistically inhibits TGF- $\beta 1$ induced epithelial-mesenchymal transition, migration and invasion of human hepatocellular carcinoma cells. Bioorg Med Chem Lett 27: 1081-1088, 2017
12. Liu Y, Yuan X, Li W, Cao Q and Shu Y: Aspirin-triggered resolvin D1 inhibits TGF- $\beta 1$-induced EMT through the inhibition of the mTOR pathway by reducing the expression of PKM2 and is closely linked to oxidative stress. Int J Mol Med 38: 1235-1242, 2016.

13. Wang H, Zhang C, Xu L, Zang K, Ning Z, Jiang F, Chi H, Zhu X and Meng Z: Bufalin suppresses hepatocellular carcinoma invasion and metastasis by targeting HIF-1 $\alpha$ via the PI3K/AKT/mTOR pathway. Oncotarget 7: 20193-20208, 2016.

14. Chang CC, Ling XH, Hsu HF, Wu JM, Wang CP, Yang JF, Fang LW and Houng JY: Siegesbeckia orientalis extract inhibits TGF $\beta 1$-induced migration and invasion of endometrial cancer cells. Molecules 21: E1021, 2016.

15. Feng LX, Sun P, Mi T, Liu M, Liu W, Yao S, Cao YM, Yu XL, Wu WY, Jiang BH, et al: Agglutinin isolated from Arisema heterophyllum Blume induces apoptosis and autophagy in A549 cells through inhibiting PI3K/Akt pathway and inducing ER stress. Chin J Nat Med 14: 856-864, 2016.

16. Li D, Han T, Liao J, Hu X, Xu S, Tian K, Gu X, Cheng $\mathrm{K}$, Li Z, Hua $\mathrm{H}$ and $\mathrm{Xu} \mathrm{J}$ : Oridonin, a promising ent-Kaurane diterpenoid lead compound. Int J Mol Sci 17: E1395, 2016.

17. Li D, Han T, Xu S, Zhou T, Tian K, Hu X, Cheng K, Li Z, Hua H and $\mathrm{Xu}$ J: Antitumor and antibacterial derivatives of oridonin: A main composition of Dong-Ling-Cao. Molecules 21: E575, 2016.

18. Lu J, Chen X, Qu S, Yao B, Xu Y, Wu J, Jin Y and Ma C: Oridonin induces G2/M cell cycle arrest and apoptosis via the PI3K/Akt signaling pathway in hormone-independent prostate cancer cells. Oncol Lett 13: 2838-2846, 2017.

19. Wang XH, Zhang SF, Bao JT and Liu FY: Oridonin synergizes with Nutlin-3 in osteosarcoma cells by modulating the levels of multiple Bcl-2 family proteins. Tumour Biol 39: 1010428317701638, 2017.

20. Xia S, Zhang X, Li C and Guan H: Oridonin inhibits breast cancer growth and metastasis through blocking the Notch signaling. Saudi Pharm J 25: 638-643, 2017.

21. Zhang Y, Wang L, Zi Y, Zhang L, Guo Y and Huang Y: Oridonin effectively reverses the drug resistance of cisplatin involving induction of cell apoptosis and inhibition of MMP expression in human acute myeloid leukemia cells. Saudi J Biol Sci 24: 678-686, 2017.

22. Gu Z, Wang X, Qi R, Wei L, Huo Y, Ma Y, Shi L, Chang Y, $\mathrm{Li} \mathrm{G}$ and Zhou L: Oridonin induces apoptosis in uveal melanoma cells by upregulation of Bim and downregulation of fatty acid synthase. Biochem Biophys Res Commun 457: 187-193, 2015.

23. Wang HJ, Li D, Yang FY, Tashiro S, Onodera S and Ikejima T: Oridonin induces human melanoma A375-S2 cell death partially through inhibiting insulin-like growth factor 1 receptor signaling. J Asian Nat Prod Res 10: 787-798, 2008.

24. Wang G, Li J, Zhang L, Huang S, Zhao X and Zhao X: Celecoxib induced apoptosis against different breast cancer cell lines by down-regulated NF- $\kappa$ B pathway. Biochem Biophys Res Commun 490: 969-976, 2017.

25. Wang JJ, Sanderson BJ and Zhang W: Significant anti-invasive activities of $\alpha$-mangostin from the mangosteen pericarp on two human skin cancer cell lines. Anticancer Res 32: 3805-3816, 2012.

26. Cui S, Wang J, Wu Q, Qian J, Yang C and Bo P: Genistein inhibits the growth and regulates the migration and invasion abilities of melanoma cells via the FAK/paxillin and MAPK pathways. Oncotarget 8: 21674-21691, 2017.

27. Wu ZY, Lien JC, Huang YP, Liao CL, Lin JJ, Fan MJ, Ko YC, Hsiao YP, Lu HF and Chung JG: Casticin inhibits A375.S2 human melanoma cell migration/invasion through downregulating $\mathrm{NF}-\kappa \mathrm{B}$ and matrix metalloproteinase-2 and -1 . Molecules 21 : $384,2016$.

28. Abu R, Jiang Z, Ueno M, Isaka S, Nakazono S, Okimura T, Cho K, Yamaguchi K, Kim D and Oda T: Anti-metastatic effects of the sulfated polysaccharide ascophyllan isolated from Ascophyllum nodosum on B16 melanoma. Biochem Biophys Res Commun 458: 727-732, 2015.

29. Saviola AJ, Burns PD, Mukherjee AK and Mackessy SP: The disintegrin tzabcanin inhibits adhesion and migration in melanoma and lung cancer cells. Int J Biol Macromol 88: 457-464, 2016.

30. Zhao S, Wang J and Qin C: Blockade of CXCL12/CXCR4 signaling inhibits intrahepatic cholangiocarcinoma progression and metastasis via inactivation of canonical Wnt pathway. J Exp Clin Cancer Res 33: 103, 2014. 
31. Hsu YY, Shi GY, Wang KC, Ma CY, Cheng TL and Wu HL: Thrombomodulin promotes focal adhesion kinase activation and contributes to angiogenesis by binding to fibronectin. Oncotarget 7: 68122-68139, 2016.

32. Shih YL, Chou HM, Chou HC, Lu HF, Chu YL, Shang HS and Chung JG: Casticin impairs cell migration and invasion of mouse melanoma B16F10 cells via PI3K/AKT and NF- $\mathrm{BB}$ signaling pathways. Environ Toxicol 32: 2097-2112, 2017.

33. Ruan JS, Liu YP, Zhang L, Yan LG, Fan FT, Shen CS, Wang AY, Zheng SZ, Wang SM and Lu Y: Luteolin reduces the invasive potential of malignant melanoma cells by targeting $\beta 3$ integrin and the epithelial-mesenchymal transition. Acta Pharmacol Sin 33: 1325-1331, 2012.

34. Feng J, Cen J, Li J, Zhao R, Zhu C, Wang Z, Xie J and Tang W: Histone deacetylase inhibitor valproic acid (VPA) promotes the epithelial mesenchymal transition of colorectal cancer cells via up regulation of Snail. Cell Adh Migr 9: 495-501, 2015.

35. Pearlman RL, Montes de Oca MK, Pal HC and Afaq F: Potential therapeutic targets of epithelial-mesenchymal transition in melanoma. Cancer Lett 391: 125-140, 2017.

36. Li F, Wang Y and Yan Y: Gambogenic acid induces cell growth inhibition, cell cycle arrest and metastasis inhibition in choroidal melanoma in a dose-dependent manner. Exp Ther Med 13: 2456-2462, 2017.

37. Zhu Y, Cheng Y, Guo Y, Chen J, Chen F, Luo R and Li A: Protein kinase D2 contributes to TNF- $\alpha$-induced epithelial mesenchymal transition and invasion via the PI3K/GSK-3 $\beta / \beta$-catenin pathway in hepatocellular carcinoma. Oncotarget 7: 5327-5341, 2016.

38. Zhou SL, Zhou ZJ, Hu ZQ, Li X, Huang XW, Wang Z, Fan J, Dai $Z$ and Zhou J: CXCR2/CXCL5 axis contributes to epithelial-mesenchymal transition of HCC cells through activating PI3K/Akt/GSK-3ß/Snail signaling. Cancer Lett 358: 124-135, 2015.

39. Sadok A, McCarthy A, Caldwell J, Collins I, Garrett MD, Yeo M, Hooper S, Sahai E, Kuemper S, Mardakheh FK and Marshall CJ: Rho kinase inhibitors block melanoma cell migration and inhibit metastasis. Cancer Res 75: 2272-2284, 2015.

40. Noguchi K, Dalton AC, Howley BV, McCall BJ, Yoshida A, Diehl JA and Howe PH: Interleukin-like EMT inducer regulates partial phenotype switching in MITF-low melanoma cell lines. PLoS One 12: e0177830, 2017.

41. Miao M, Yan X, Guo L and Shao S: Effects of the Rabdosia rubescens total flavonoids on focal cerebral ischemia reperfusion model in rats. Saudi Pharm J 25: 607-614, 2017.

42. Ren CM, Li Y, Chen QZ, Zeng YH, Shao Y, Wu QX, Yuan SX, Yang JQ, Yu Y, Wu K, et al: Oridonin inhibits the proliferation of human colon cancer cells by upregulating BMP7 to activate p38 MAPK. Oncol Rep 35: 2691-2698, 2016.

43. Zhao J, Zhang M, He P, Zhao J, Chen Y, Qi J and Wang Y: Proteomic analysis of oridonin-induced apoptosis in multiple myeloma cells. Mol Med Rep 15: 1807-1815, 2017.

44. Hao Y, Zhao F, Luo Y, Zhang M and Li S: Inhibitory effect of oridonin on proliferation of RPMI8226 cells and the possible underlying mechanism. J Tradit Chin Med 36: 225-230, 2016.

45. Staton CA, Reed MW and Brown NJ: A critical analysis of current in vitro and in vivo angiogenesis assays. Int J Exp Pathol 90: 195-221, 2009.

46. Nakamura K, Peng Y, Utsumi F, Tanaka H, Mizuno M, Toyokuni S, Hori M, Kikkawa F and Kajiyama H: Novel intraperitoneal treatment with non-thermal plasma-activated medium inhibits metastatic potential of ovarian cancer cells. Sci Rep 7: 6085,2017
47. Wu QX, Yuan SX, Ren CM, Yu Y, Sun WJ, He BC and Wu K Oridonin upregulates PTEN through activating p38 MAPK and inhibits proliferation in human colon cancer cells. Oncol Rep 35: 3341-3348, 2016

48. Xia R, Chen SX, Qin Q, Chen Y, Zhang WW, Zhu RR and Deng AM: Oridonin suppresses proliferation of human ovarian cancer cells via blockage of mTOR signaling. Asian Pac J Cancer Prev 17: 667-671, 2016.

49. Bauer D, Werth F, Nguyen HA, Kiecker F and Eberle J: Critical role of reactive oxygen species (ROS) for synergistic enhancement of apoptosis by vemurafenib and the potassium channel inhibitor TRAM-34 in melanoma cells. Cell Death Dis 8: e2594, 2017.

50. Wang Y, Sun Y, Wu Y and Zhang J: Cucurbitacin E inhibits osteosarcoma cells proliferation and invasion through attenuation of PI3K/AKT/mTOR signaling. Biosci Rep 36: e00405, 2016.

51. Cha BK, Kim YS, Hwang KE, Cho KH, Oh SH, Kim BR, Jun HY, Yoon KH, Jeong ET and Kim HR: Celecoxib and sulindac inhibit TGF- $\beta 1$-induced epithelial-mesenchymal transition and suppress lung cancer migration and invasion via downregulation of sirtuin 1. Oncotarget 7: 57213-57227, 2016.

52. Lee YJ and Han HJ: Troglitazone ameliorates high glucose-induced EMT and dysfunction of SGLTs through PI3K/Akt, GSK-3 $\beta$, Snaill, and $\beta$-catenin in renal proximal tubule cells. Am J Physiol Renal Physiol 298: F1263-F1275, 2010.

53. Baek SH, Ko JH, Lee JH, Kim C, Lee H, Nam D, Lee J, Lee SG, Yang WM, Um JY, et al: Ginkgolic acid inhibits invasion and migration and TGF- $\beta$-induced EMT of lung cancer cells through PI3K/Akt/mTOR inactivation. J Cell Physiol 232: 346-354, 2017.

54. Petanidis S, Kioseoglou E, Domvri K, Zarogoulidis P, Carthy JM, Anestakis D, Moustakas A and Salifoglou A: In vitro and ex vivo vanadium antitumor activity in (TGF- $\beta$ )-induced EMT. Synergistic activity with carboplatin and correlation with tumor metastasis in cancer patients. Int J Biochem Cell Biol 74: 121-134, 2016.

55. Balakrishnan S, Mukherjee S, Das S, Bhat FA, Raja Singh P, Patra CR and Arunakaran J: Gold nanoparticles-conjugated quercetininduces apoptosis via inhibition of EGFR/PI3K/Akt-mediated pathway in breast cancer cell lines (MCF-7 and MDA-MB-231). Cell Biochem Funct 35: 217-231, 2017.

56. Chen XH, Lu LL, Ke HP, Liu ZC, Wang HF, Wei W, Qi YF, Wang HS, Cai SH and Du J: The TGF- $\beta$-induced up-regulation of NKG2DLs requires AKT/GSK-3 $\beta$-mediated stabilization of SP1. J Cell Mol Med 21: 860-870, 2017.

57. He F, Chen H, Yang P, Wu Q, Zhang T, Wang C, Wei J, Chen Z,

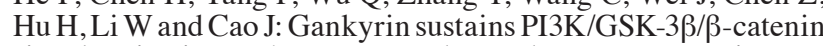
signal activation and promotes colorectal cancer aggressiveness and progression. Oncotarget 7: 81156-81171, 2016.

58. Qin CD, Ma DN, Ren ZG, Zhu XD, Wang CH, Wang YC, Ye BG, Cao MQ, Gao DM and Tang ZY: Astragaloside IV inhibits metastasis in hepatoma cells through the suppression of epithelial-mesenchymal transition via the Akt/GSK-3 $\beta / \beta$-catenin pathway. Oncol Rep 37: 1725-1735, 2017.

59. Guo H, Luo H, Yuan H, Xia Y, Shu P, Huang X, Lu Y, Liu X, Keller ET, Sun D, et al: Litchi seed extracts diminish prostate cancer progression via induction of apoptosis and attenuation of EMT through Akt/GSK-3 $\beta$ signaling. Sci Rep 7: 41656, 2017. 